\title{
Battelle Energy Alliance, LLC, Continuity Readiness Assurance Report - Fiscal Year 2014
}

\author{
Brandon C. Stucki
}

September 2014

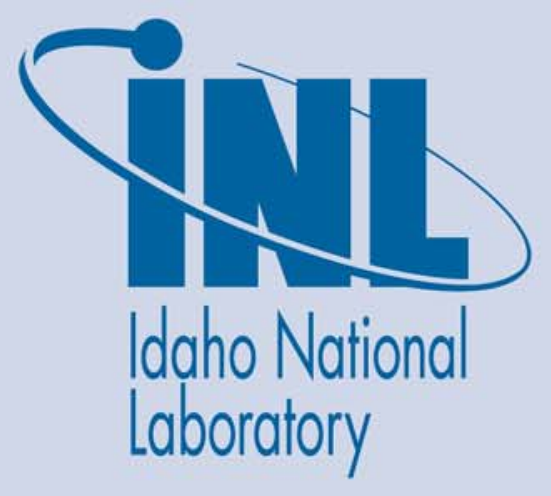

The INL is a U.S. Department of Energy National Laboratory operated by Battelle Energy Alliance 
INL/EXT-15-33055

\title{
Battelle Energy Alliance, LLC, Continuity Readiness Assurance Report - Fiscal Year 2014
}

\author{
Brandon C. Stucki
}

September 2014

\author{
Idaho National Laboratory \\ Idaho Falls, Idaho 83415
}

http://www.inl.gov

Prepared for the

U.S. Department of Energy

Office of Nuclear Science

Under DOE Idaho Operations Office

Contract DE-AC07-05ID14517 


\section{DISCLAIMER}

This information was prepared as an account of work sponsored by an agency of the U.S. Government. Neither the U.S. Government nor any agency thereof, nor any of their employees, makes any warranty, expressed or implied, or assumes any legal liability or responsibility for the accuracy, completeness, or usefulness, of any information, apparatus, product, or process disclosed, or represents that its use would not infringe privately owned rights. References herein to any specific commercial product, process, or service by trade name, trade mark, manufacturer, or otherwise, does not necessarily constitute or imply its endorsement, recommendation, or favoring by the U.S. Government or any agency thereof. The views and opinions of authors expressed herein do not necessarily state or reflect those of the U.S. Government or any agency thereof. 

Emergency Management

\section{Battelle Energy Alliance, LLC, Continuity Readiness Assurance Report - Fiscal Year 2014}

INL/EXT-14-33055

Revision 0

September 2014
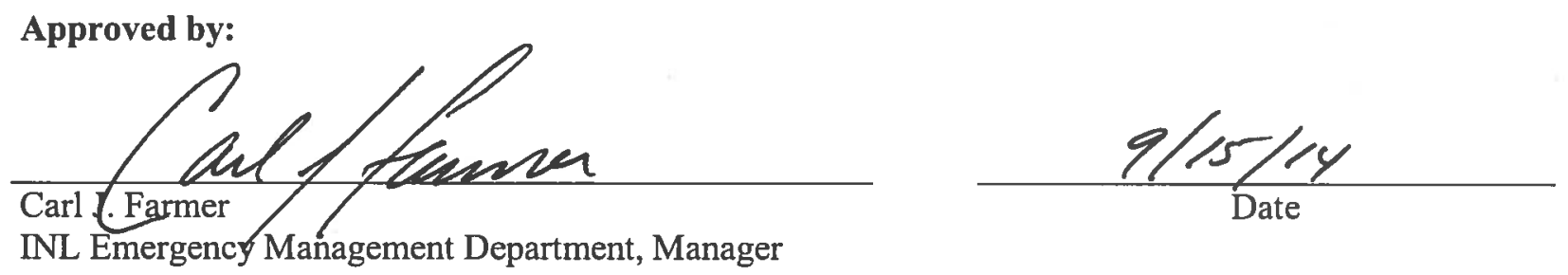



\begin{abstract}
Battelle Energy Alliance, LLC, the prime contractor for Idaho National Laboratory (INL), provides this Continuity Readiness Assurance Report (CRAR) in accordance with DOE O 150.1, "Continuity Programs." This CRAR documents the readiness of the INL Continuity of Operations Program using emergency response planning, recovery actions, and preparedness activities, and where applicable, summarizes and/or provides supporting information for Fiscal Year 2014. This CRAR also provides goals and achievements for Fiscal Year 2015.

Specifically, this CRAR assures the Department of Energy Idaho Operations Office that the emergency capabilities at INL are sufficient to implement the INL Continuity of Operations Plan.
\end{abstract}




\section{CONTENTS}

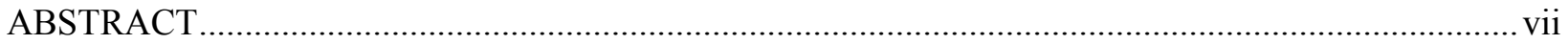

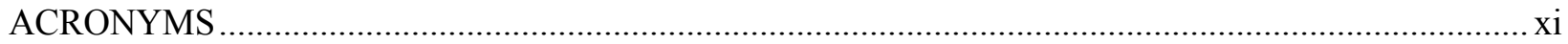

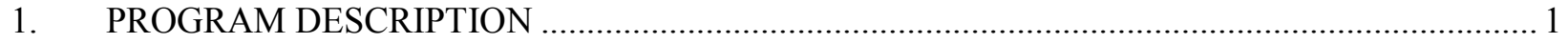

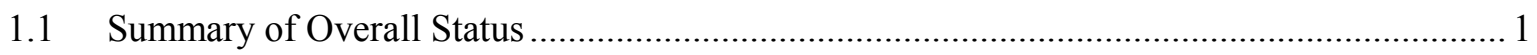

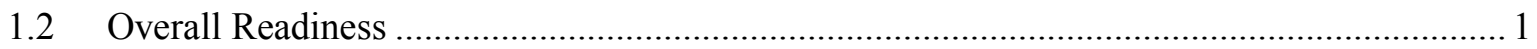

1.3 Limiting Factors Preventing Accomplishment of Essential Functions .................................. 2

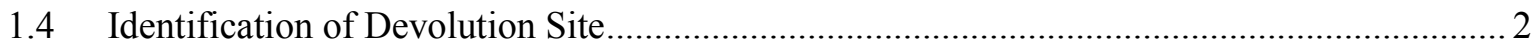

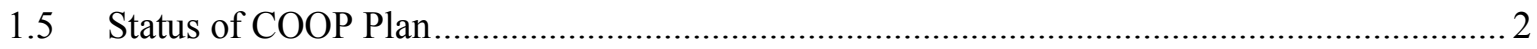

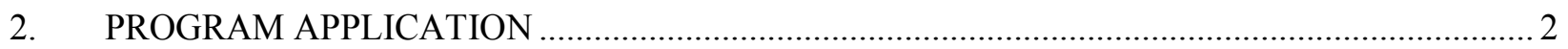

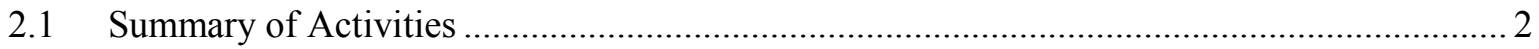

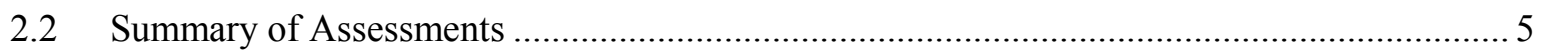

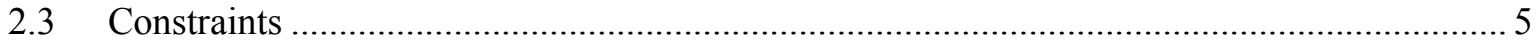

2.4 Program Improvements/Issues/Needs ........................................................................ 5

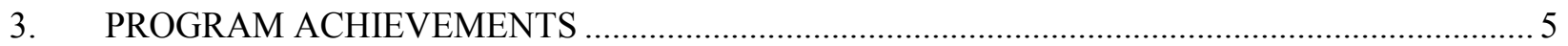

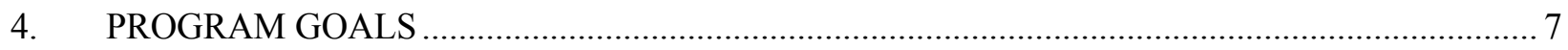

TABLES

Table 1. Equipment checks, testing, training, tabletop drills, and exercises............................................ 3

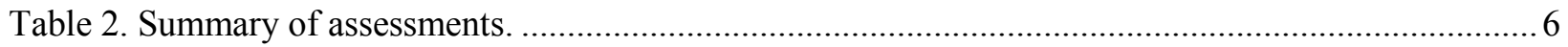




\section{ACRONYMS}

AOF alternate operating facility

BEA Battelle Energy Alliance, LLC

CEMT continuity emergency management team

CERG continuity emergency response group

COOP continuity of operations

CRAR Continuity Readiness Assurance Report

DOE Department of Energy

DOE-ID Department of Energy Idaho Operations Office

ESA essential supporting activity

FY Fiscal Year

INL Idaho National Laboratory

LSPT limited scope performance test

PMEF primary mission essential function

WCC Warning Communications Center 


\section{Battelle Energy Alliance, LLC, Continuity Readiness Assurance Report - Fiscal Year 2014 \\ 1. PROGRAM DESCRIPTION}

Battelle Energy Alliance, LLC (BEA), is the Department of Energy (DOE) managing and operating contractor for Idaho National Laboratory (INL) at the INL Site near Idaho Falls, Idaho, and Research and Education Campus in Idaho Falls. The INL Continuity of Operations (COOP) Program is an integrated function of the INL Emergency Management Department. PLN-4267, "Idaho National Laboratory Continuity of Operations Plan," was developed in accordance with the applicable requirements in DOE O 150.1, "Continuity Programs," and National Security Presidential Directive-51/Homeland Security Presidential Directive-20. The INL COOP establishes procedures used by BEA during a continuity event. The primary mission essential function (PMEF) is to maintain the safety and security of special nuclear material at INL. The PLN-4267 is an integrated function of the DOE Idaho Operations Office (DOE-ID) and BEA and managed by BEA. It is intended that INL will implement PLN-4267 in conjunction with the DOE-ID COOP Plan (11.OD.02).

PLN-4267 and PLN-2420, "BEA Epidemic/Pandemic Influenza Plan," define the elements of the INL COOP Program.

PLN-4267 applies to all INL personnel and INL programs and essential supporting activities (ESAs) related to the performance of the INL PMEF. The objectives of PLN-4267 are to:

- Maintain a high level of readiness

- Protect personnel and visitors from dangerous conditions

- Ensure INL can fulfill its responsibilities for protecting the federal government's legal, financial, and security interests, including critical operational oversight, even when conditions cause INL to operate without its usual support systems and facilities

- Provide at least a minimum level of service required to meet DOE-ID's needs, especially those required at times of local or regional emergencies

- Provide the initial framework for response to any incapacitating event by mission essential personnel to ensure the INL PMEF and ESAs can be performed.

\subsection{Summary of Overall Status}

PLN-4267 establishes the COOP procedures used by BEA and was initially approved by DOE-ID in September 2012. PLN-4267 has been in its second year of implementation for Fiscal Year (FY) 2014. FY-2014 provided the opportunity for the development and maturity of the INL COOP Program. With the successful completion of several assessments, tabletop drills, and the annual combined exercise during FY-2014, BEA is progressively enhancing the capabilities in establishing a robust and sustainable COOP program.

\subsection{Overall Readiness}

PLN-4267 supports a high level of confidence in continuing the INL PMEF despite circumstances that may limit access to resources, including personnel, facilities, information systems, and communications. The INL PMEF has line-of-sight to, or supports the performance of, the DOE-ID PMEF and ultimately the DOE mission essential functions/PMEFs and national essential functions, as required by DOE O 150.1 and National Security Presidential Directive-51/Homeland Security Presidential Directive-20. 
To ensure the overall readiness of the INL COOP Program, the program has established the framework and associated mechanisms for assuring that PLN-4267, implementing procedures, and resources are adequate by ensuring that they are sufficiently maintained, exercised, and evaluated (including assessments and corrective actions) and that appropriate and timely improvements are made in response to needs identified through coordinated and comprehensive COOP planning, resource allocation, training and drills, exercises, and evaluations. Continuous improvement for ensuring overall readiness comes from implementing corrective actions for findings (such as deficiencies, weaknesses, lessons learned, opportunities for improvement) in all types of evaluations, including both internal and external evaluations.

\subsection{Limiting Factors Preventing Accomplishment of Essential Functions}

Currently, there are no factors that limit BEA's ability to accomplish designated essential functions.

\subsection{Identification of Devolution Site}

Devolution of command and control refers to the situation in which the INL Site is affected to such a degree that it is unable to function. Authority and responsibility must then be transferred. Should this occur, authority and responsibilities are transferred to the agency not affected. In this case, leadership is assured via the orders of succession, under direction of the senior successor, who reconstitutes a continuity emergency response group (CERG). The CERG assumes responsibility for performing the INL PMEF and as many of the ESAs as possible, or notifies DOE of the inability to perform the functions.

\subsection{Status of COOP Plan}

PLN-4267 was implemented in September 2012. PLN-4267 must be reviewed annually, at a minimum, to ensure it is accurate and current. The INL COOP coordinator ensures PLN-4267 is reviewed annually and updated, as necessary. As part of the annual review, the INL COOP coordinator determines whether INL capabilities are sufficient and whether PLN-4267 meets all essential requirements identified in DOE O 150.1. Other aspects of PLN-4267 review include the following:

- Maintaining overall PLN-4267 currency and readiness, to include procedures, equipment, systems, personnel, and rosters

- Addressing and resolving PLN-4267 policy issues

- Advising the INL COOP manager on COOP-related matters

- Coordinating among related plans

- Conducting tests, training, and exercises

- Updating PLN-4267 to incorporate lessons learned from tests, drills, exercises, and any actual events that occurred during the FY.

\section{PROGRAM APPLICATION}

\subsection{Summary of Activities}

Table 1 identifies the equipment checks, testing, training, tabletop drills, and exercises performed during FY-2014 for BEA. Some of the tasks and criteria identified in Table 1 were generated from INL COOP Program goals for FY-2013 (CCN 231332, dated September 11, 2013). 
Table 1. Equipment checks, testing, training, tabletop drills, and exercises.

\begin{tabular}{|c|c|c|c|c|c|}
\hline \\
\hline Type & Subtype & Who & Capability & Task & Criteria \\
\hline $\begin{array}{l}\text { General } \\
\text { employee } \\
\text { training }\end{array}$ & $\begin{array}{l}\text { Web-based } \\
\text { training }\end{array}$ & $\begin{array}{l}\text { All BEA employees at INL, } \\
\text { including new hires as part } \\
\text { of initial requirements }\end{array}$ & COOP awareness & $\begin{array}{l}\text { Familiarize BEA employees } \\
\text { at INL with COOP alerts, } \\
\text { notifications, and } \\
\text { deployment procedures }\end{array}$ & $\begin{array}{l}\text { COOP concepts, philosophy, } \\
\text { and expectations understood }\end{array}$ \\
\hline CERG training & $\begin{array}{l}\text { Classroom } \\
\text { training }\end{array}$ & INL CERG & $\begin{array}{l}\text { Qualification and } \\
\text { annual refresher } \\
\text { training }\end{array}$ & $\begin{array}{l}\text { Familiarize CERG members } \\
\text { with communications, } \\
\text { available } \mathrm{AOF}^{1} \text { resources, } \\
\text { COOP concepts, and CERG } \\
\text { responsibilities and } \\
\text { expectations }\end{array}$ & $\begin{array}{l}\text { COOP requirements and } \\
\text { expectations understood }\end{array}$ \\
\hline $\begin{array}{l}\text { LSPT, }{ }^{1} \\
\text { equipment }\end{array}$ & $\begin{array}{l}\text { Test } \\
\text { (maintenance) }\end{array}$ & $\begin{array}{l}\text { INL COOP coordinator, } \\
\text { INL CERG, and INL } \\
\text { mission critical personnel }\end{array}$ & $\begin{array}{l}\text { Communications and } \\
\text { CERG functions }\end{array}$ & $\begin{array}{l}\text { Check equipment and } \\
\text { documentation for primary } \\
\text { and backup AOFs }\end{array}$ & $\begin{array}{l}\text { All systems are functional, } \\
\text { including primary and } \\
\text { alternate communication } \\
\text { pathways and equipment }\end{array}$ \\
\hline $\begin{array}{l}\text { LSPT, } \\
\text { notification }\end{array}$ & Test & $\begin{array}{l}\text { INL COOP coordinator, } \\
\text { WCC, }{ }^{1} \text { and INL CERG }\end{array}$ & $\begin{array}{l}\text { Communications } \\
\text { (Everbridge System) }\end{array}$ & $\begin{array}{l}\text { Test ability to notify CERG } \\
\text { members }\end{array}$ & $\begin{array}{l}\text { Notification is received } \\
\text { (quarterly test) }\end{array}$ \\
\hline LSPT, operations & $\begin{array}{l}\text { Test } \\
\text { (maintenance) }\end{array}$ & $\begin{array}{l}\text { INL COOP coordinator and } \\
\text { INL CERG }\end{array}$ & Vital records & $\begin{array}{l}\text { Access redundant source of } \\
\text { vital records at AOFs }\end{array}$ & $\begin{array}{l}\text { Vital records are accessible } \\
\text { (quarterly update) }\end{array}$ \\
\hline $\begin{array}{l}\text { LSPT, alternate } \\
\text { power }\end{array}$ & $\begin{array}{l}\text { Test } \\
\text { (maintenance) }\end{array}$ & $\begin{array}{l}\text { INL COOP coordinator and } \\
\text { INL Protective Force }\end{array}$ & Portable generators & $\begin{array}{l}\text { Check operability of } \\
\text { portable generators and } \\
\text { ensure INL Protective Force } \\
\text { is maintaining equipment }\end{array}$ & $\begin{array}{l}\text { Maintenance schedule is } \\
\text { maintained }\end{array}$ \\
\hline $\begin{array}{l}\text { LSPT, } \\
\text { communications }\end{array}$ & $\begin{array}{l}\text { Test } \\
\text { (maintenance/ } \\
\text { training) }\end{array}$ & $\begin{array}{l}\text { INL COOP coordinator and } \\
\text { INL Protective Force }\end{array}$ & Satellite phones & $\begin{array}{l}\text { Provide training, followed } \\
\text { by simple test, to familiarize } \\
\text { INL Protective Force with } \\
\text { satellite phone capabilities }\end{array}$ & $\begin{array}{l}\text { Equipment operation is } \\
\text { adequate }\end{array}$ \\
\hline Tabletop drill & $\begin{array}{l}\text { Training } \\
\text { development }\end{array}$ & $\begin{array}{l}\text { INL CERG; Facilities and } \\
\text { Site Services; Environment, } \\
\text { Safety, and Health; and } \\
\text { emergency fuel contractor }\end{array}$ & $\begin{array}{l}\text { Emergency fuel } \\
\text { supplies and ability to } \\
\text { refuel during COOP } \\
\text { event }\end{array}$ & $\begin{array}{l}\text { Demonstrate and configure } \\
\text { layout of portable fuel pump }\end{array}$ & $\begin{array}{l}\text { Appropriate portable fuel } \\
\text { pump capabilities } \\
\text { understood }\end{array}$ \\
\hline
\end{tabular}


Table 1. (continued).

\begin{tabular}{|c|c|c|c|c|c|}
\hline Type & Subtype & Who & Capability & Task & Criteria \\
\hline Tabletop drill & $\begin{array}{l}\text { Exercise } \\
\text { development }\end{array}$ & $\begin{array}{l}\text { INL CERG, Information } \\
\text { Management, Cyber } \\
\text { Security, and DOE-ID }\end{array}$ & $\begin{array}{l}\text { Annual exercise } \\
\text { development }\end{array}$ & $\begin{array}{l}\text { Interface with offsite } \\
\text { agencies }\end{array}$ & $\begin{array}{l}\text { Information technology is } \\
\text { available and interoperable } \\
\text { communication support is } \\
\text { provided }\end{array}$ \\
\hline Tabletop drill & $\begin{array}{l}\text { Equipment } \\
\text { upgrade }\end{array}$ & $\begin{array}{l}\text { INL COOP coordinator and } \\
\text { WCC }\end{array}$ & $\begin{array}{l}\text { Notification system } \\
\text { upgrade }\end{array}$ & $\begin{array}{l}\text { Discuss notification system } \\
\text { capabilities and provide } \\
\text { automated system to notify } \\
\text { CERG members }\end{array}$ & $\begin{array}{l}\text { WCC is capable of } \\
\text { activating CERG using } \\
\text { Everbridge System }\end{array}$ \\
\hline Exercise & $\begin{array}{l}\text { Annual } \\
\text { exercise/ } \\
\text { cyber security }\end{array}$ & $\begin{array}{l}\text { INL CERG; DOE-ID } \\
\text { CERG; CH2M-WG Idaho, } \\
\text { LLC, CERG; Idaho } \\
\text { Treatment Group, LLC, } \\
\text { CERG; Emergency } \\
\text { Operations Center; Joint } \\
\text { Information Center; and } \\
\text { WCC }\end{array}$ & $\begin{array}{l}\text { Integration of multiple } \\
\text { CERG and other } \\
\text { COOP-affiliated } \\
\text { organizations }\end{array}$ & $\begin{array}{l}\text { Conduct exercise to provide } \\
\text { selected INL CERG } \\
\text { members and supporting } \\
\text { personnel opportunity to } \\
\text { respond to and mitigate } \\
\text { COOP event }\end{array}$ & $\begin{array}{l}\text { Activation and relocation } \\
\text { process is functional, } \\
\text { operations can be conducted } \\
\text { from AOFs, and } \\
\text { reconstitution (recovery) } \\
\text { stage can be completed }\end{array}$ \\
\hline 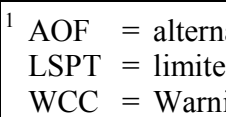 & $\begin{array}{l}\text { erating facility } \\
\text { e performance }\end{array}$ & & & & \\
\hline
\end{tabular}




\subsection{Summary of Assessments}

The INL Issues Management Program ensures issues that have a reasonable potential to cause adverse operational, environmental, safety and health, or quality assurance consequences are documented and resolved in an effective and timely manner. The program is designed to be an integrated BEA process that enables management to understand and prioritize, based on risk and significance, the correction of issues. The program also provides for ensuring that adequate corrective actions are implemented to prevent recurrence of undesirable events or conditions through appropriate causal analysis, corrective action, verification, and follow-up actions.

Issues identified in the INL COOP Program during exercises and actual emergencies are noted and discussed during event critiques. Methods are determined to resolve the concerns and a schedule is prepared to implement the resolution. Once identified, issues are screened and, if appropriate, entered into the Laboratory Protection LabWay for electronic tracking. Corrective action plans are prepared and the issues tracked until resolved.

Table 2 identifies the issues that the INL COOP Program had identified and entered into the Laboratory Protection LabWay during FY-2014.

\subsection{Constraints}

There are no constraints at this time.

\subsection{Program Improvements/lssues/Needs}

Table 2 lists those issues from assessments and evaluations of improvements that the INL COOP Program had identified and entered into the Laboratory Protection LabWay during FY-2014. The issues listed in Table 2 were addressed and closed during FY-2014, with no remaining issues carrying into FY-2015.

\section{PROGRAM ACHIEVEMENTS}

FY-2014 has provided several opportunities for the growth and further development of the INL COOP Program. Several goals set during FY-2013 were successfully completed during the FY-2014 assessment, drills/exercise, and training opportunities.

Following the FY-2013 exercise, it was suggested to implement a CEMT checklist to provide an overview of what essential services must be addressed during a COOP event. The checklist was implemented in FY-2014, and training was provided on how to use the checklist effectively. The checklist was used during the FY-2014 exercise and proved beneficial in managing the event.

The INL COOP Program upgraded its notification process. Adding the Everbridge System to the notification process allows the WCC to notify CERG members using the automated system thus enabling the WCC to focus on other tasks in an emergency situation. Several test and training opportunities provided evidence that the system was of value.

Annual COOP Orientation training was revised and improved in the way it has been issued to all contractors at INL. On a yearly basis, the training provides an overview on COOP-related topics to inform the general employee body of its capabilities. Along with the training orientation, all new hires are offered reading material along with their new hire packets. This orientation is presented in a way that all the employees at INL can stay informed of COOP activities.

PLN-2420 was reviewed and revised to reflect the latest updates pertaining to epidemic/pandemic planning. 
Table 2. Summary of assessments.

\begin{tabular}{|c|c|c|}
\hline Issue & Action & Status \\
\hline $\begin{array}{l}\text { Tabletop drill: Validate emergency fuel supplies and the ability } \\
\text { to refuel during a COOP event. Identify a method for accessing } \\
\text { and utilizing emergency fuel storage. }\end{array}$ & $\begin{array}{l}\text { A portable, independent fuel transfer pump has been procured. } \\
\text { Emergency fuel storage has been identified. } \\
\text { Action: Identified the portable fuel pump's capabilities and the } \\
\text { proper use of the equipment. }\end{array}$ & Closed \\
\hline $\begin{array}{l}\text { Tabletop drill: Identify potential perceived vulnerabilities to the } \\
\text { PMEF due to cyber security challenges with simulated COOP } \\
\text { scenarios. Identified three critical data systems (SRDnet, Local } \\
\text { Area Nuclear Material Accountability Software, and HSPD-12) } \\
\text { in the tabletop drill discussion that should be evaluated. }\end{array}$ & $\begin{array}{l}\text { Evaluate the potential impacts of SRDnet, Local Area Nuclear } \\
\text { Material Accountability Software, and HSPD- } 12 \text { being } \\
\text { inoperable, and consider identifying these data systems as vital } \\
\text { files, records, and databases. } \\
\text { Action: Evaluated and determined not to add these data systems } \\
\text { to the current critical data system logs. }\end{array}$ & Closed \\
\hline $\begin{array}{l}\text { FY-2013 exercise: Validate integration among multiple CERG } \\
\text { organizations and other COOP-affiliated organizations. }\end{array}$ & & Closed \\
\hline Provide additional training on WebEOC and iMap. & $\begin{array}{l}\text { Action: Coordinated a training session to familiarize CERG } \\
\text { members with the use of WebEOC and iMap. }\end{array}$ & Closed \\
\hline $\begin{array}{l}\text { Provide structured and assigned seating in the COOP } \\
\text { Command Room. }\end{array}$ & $\begin{array}{l}\text { Action: Developed assigned seating for continuity emergency } \\
\text { management team (CEMT) members. }\end{array}$ & Closed \\
\hline $\begin{array}{l}\text { Provide response guidance binders with COOP resources (to } \\
\text { include a CERG organizational structure chart) and } \\
\text { decision-making tools. }\end{array}$ & Action: Developed a CEMT checklist and binder. & Closed \\
\hline $\begin{array}{l}\text { LSPT, notification: Identified the need to upgrade the } \\
\text { notification process to an automotive system to notify the } \\
\text { CERG. }\end{array}$ & $\begin{array}{l}\text { Action: Implemented the Everbridge System for use by the WCC } \\
\text { to notify the CERG. }\end{array}$ & Closed \\
\hline $\begin{array}{l}\text { LSPT, alternate power: Identified and submitted } \\
\text { recommendation to the Protective Force to implement a } \\
\text { maintenance schedule for the portable generators. }\end{array}$ & $\begin{array}{l}\text { Action: Submitted recommendation to the INL Protective Force } \\
\text { to implement a maintenance schedule for the portable generators. }\end{array}$ & Closed \\
\hline
\end{tabular}




\section{PROGRAM GOALS}

For FY-2015, the INL COOP Program is looking forward to another successful year of implementing PLN-4267. Realizing there is always room for improvement for the growth of the program, BEA has identified areas to improve proficiency in the way INL manages the INL COOP Program. Along with evaluating new ideas, the program will continue to provide training opportunities and provide assessments of the program to further enhance its capabilities.

INL COOP Program goals for FY-2015, many of which are driven by DOE O 150.1, are as follows:

- Conduct a COOP full-size exercise to test INL COOP response.

- Train and exercise to CERG responsibilities defined in PLN-2420.

- Provide CERG orientation on responsibilities and equipment.

- Provide all BEA employees at INL awareness training on COOP alerts, notifications, and accountability.

- Review PLN-4267 and update, as necessary, to include incorporating changes in policy and philosophy and managing distribution of plan revisions.

- Maintain and update, as needed, orders of succession of current incumbents and designated successors.

- Update vital records to ensure they are current.

- Update CERG rosters of positions and information, if needed.

- Develop tabletop drill subtypes that consider training development opportunities and/or vulnerability assessments.

- Conduct LSPTs on equipment, the notification process, vital records, emergency power, and the accountability process.

- Evaluate and look for ways to improve interaction with the Emergency Operations Center Emergency Response Organization to ensure a strong cohesiveness in preparing for what emergencies might occur in the future.

- Track and evaluate the participation of CERG members on their willingness to participate in training activities. In doing so, ensure the INL COOP Program has meaningful training activities that encourage participation.

- Follow the development and implementation of DOE O 150.1A, "Continuity Programs," and update PLN-4267, if necessary.

- Evaluate the emergency food and water supply for mission critical personnel and verify maintenance is up to date.

- Evaluate and look for ways to improve interfaces and integration opportunities to work with

COOP-related organizations. 